\title{
SCHISTIDIUM AUSTROSIBIRICUM SP. NOV. AND S. SCABRIPILUM SP. NOV. (GRIMMIACEAE, BRYOPHYTA) - TWO CLOSELY RELATED SPECIES FROM ASIAN RUSSIA
}

\author{
SCHISTIDIUM AUSTROSIBIRICUM SP. NOV. AND S. SCABRIPILUM SP. NOV. \\ (GRIMMIACEAE, ВRYOРНYТА) - ДВА НОВЫХ БЛИЗКОРОДСТВЕННЫХ ВИДА \\ ИЗ АЗИАТСКОЙ ЧАСТИ РОССИИ
}

\author{
ElENA A. IGNATOVA ${ }^{1}$, HANS H. BLOM ${ }^{2}$ \& OXANA I. KUZNETSOVA ${ }^{3}$ \\ ЕЛЕНА А. ИГНАТОВА ${ }^{1}$, ХАНС Х. БЛОМ $^{2}$, ОКСАНА И. КУЗНЕЦОВА ${ }^{3}$
}

Abstract

Two new species of Schistidium are described from Asian Russia. Their distinctness is supported by nrDNA ITS1-2 sequence data. S. austrosibiricum was not previously differentiated from $S$. sinensiapocarpum, mainly due to their similarly long and sharply serrate hair-points in stem and perichaetial leaves and papillose dorsal side of costa. However, they differ in leaf size and shape, hair-points flatness and leaf lamina areolation. S. austrosibiricum is known from southernmost mountain areas of Asian Russia, while $S$. sinensiapocarpum is a widespread circumholarctic montane species. The second species, S. scabripilum is morphologically similar to $S$. echinatum, and some specimens were previously referred to it. The main differences between them concern hair-point length and structure, including length of protruding spinulae and their angle with the hair-point axis. However, they belong to different clades in the molecular phylogenetic tree and possess different distribution patterns. $S$. scabripilum is a northern Asian species, found in the Putorana Plateau, southern Taimyr, Yakutia and Chukotka, while S. echinatum is known from the Alps, Caucasus and Ural mountains, and in western North America. Description, illustrations, distribution and ecological data are provided for the new species, and comparison with similar species is given.

Резюме

Два новых вида Schistidium описаны из Азиатской части России. Отличия между ними подтверждены данными по последовательностям ITS1-2 ядерной ДНК. S. austrosibiricum ранее не отличали от $S$. sinensiapocarpum, в основном из-за сходства в строении гиалиновых волосков в стеблевых и перихециальных листьях - длинных и остро пильчатых, а также папиллозной на дорсальной поверхности жилке. Дополнительное изучение морфологических признаков позволило выявить отличия между этими видами в размерах и форме листьев, степени уплощенности гиалиновых волосков, размерах клеток пластинки листа и выемчатости клеточных стенок. S. austrosibiricum распространен в горных районах юга Сибири, тогда как $S$. sinensiapocarpum является более широко распространенным циркумголарктическим горным видом. Второй вид, S. scabripilum, по морфологическим признакам сходен с S. echinatum, и некоторые его образцы ранее относили к последнему виду. Их основные отличия заключаются в длине и характере орнаментации поверхности гиалиновых волосков, а именно в длине шипиков на дорсальной поверхности волоска и степени их отогнутости по отношению к оси волоска. Несмотря на значительное морфологическое сходство, эти два вида попадают в разные, далекие друг от друга клады молекулярнофилогенетического дерева. Они также имеют различия в распространении: S. scabripilum встречается в северных регионах Азиатской России, тогда как S. echinatum известен из Альп в Центральной Европе, с Кавказа, Урала и с запада Северной Америки. Приводятся описания, иллюстрации и данные об экологии и распространении новых видов, а также их сравнение с морфологически сходными видами.

KEYWORDS: taxonomy, mosses, new species, ITS

\footnotetext{
1 - Faculty of Biology, Moscow State University, Moscow 119991 Russia - Россия 119991 Москва, Московский государственный университет, Биологический факультет, каф. геоботаники; e-mail: arctoa@list.ru

2 - Norwegian Institute of Bioeconomy Research, Fanaflaten 4, N-5244 Bergen, Norway; hans.blom@nibio.no

3 - Main Botanical Garden, Russian Academy of Sciences, Botanicheskaya Str., 4, Moscow 127276 Russia - Россия 127276 Москва, Ботаническая 4, ГБС РАН, e-mails: oikuznets@gmail.com
} 


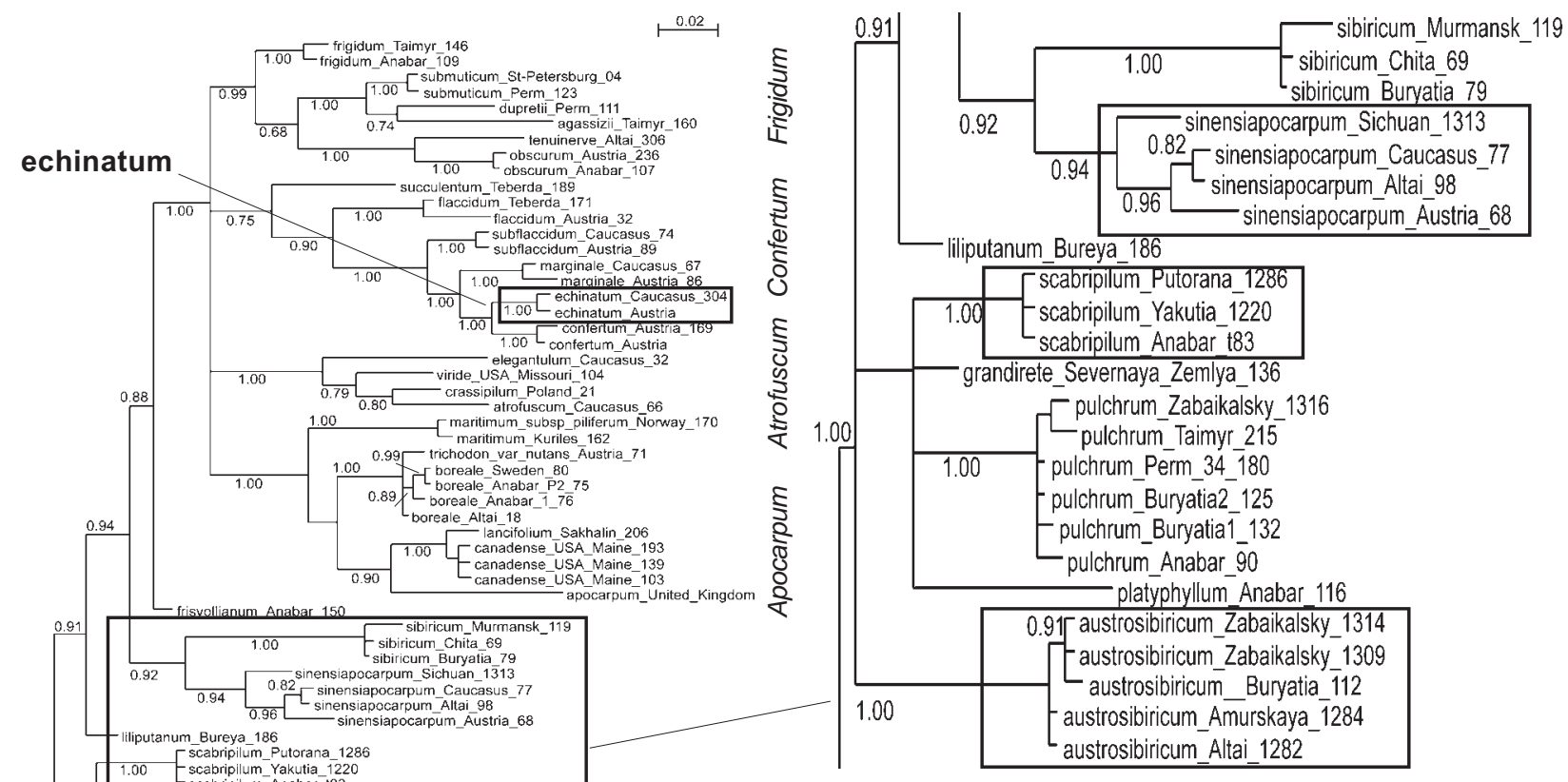

Fig. 1. Bayesian phylogenetic tree of Schistidium based on ITS1-2 sequences, showing unrelated position of $S$. echinatum, nested in Confertumclade, with S. scabripilum found in basal polytomy. Clade names are according to Blom (1996) and Ignatova et al. (2010). Posterior probabilities $>70$ are shown at branches.

\section{INTRODUCTION}

The genus Schistidium is one of the most taxonomically difficult among moss genera. Following the revision of Blom (1996), a narrow species concept which has been supported by molecular studies (Goryunov et al., 2007; Milyutina et al., 2010) has become widely accepted during the last decades. A considerable number of new species have been described from both the Northern and Southern Hemisphere, and some forgotten species have been resurrected. A brief overview of recent literature concerning these novelties is given by Blom et al. (2016). The vast territory of Russia has quite expectedly turned out to be a source of material for the description of new species of Schistidium. Six new species were revealed there (Ignatova et al., 2010). Two of them have restricted distribution areas in the Russian Far East: S. bakalinii is hitherto known only from Kuril Islands (Shikotan and Iturup), S. frahmianum from Chukotka and a single locality in northern Yakutia (Ochyra \& Afonina, 2010; Ignatova' unpublished data). Two other species, $S$. sibiricum and $S$. tenuinerve, have comparatively wide distributions in Asian Russia, and are also known from a few disjunct localities in northern Europe (Ignatova et al., 2010; Ellis et al., 2016). The remaining species, S. obscurum and $S$. succulentum, are characterized by even wider, though more scattered distributions (Ignatova et al., 2010). The distinctness of most of these species was disclosed by the help of molecular phylogenetic analysis based on ITS1-2 sequence data, a marker which has proven very useful in resolving the species taxonomy of Schistidium (Milyutina et al., 2010; Hofbauer et al., 2016).

Ongoing bryofloristic exploration of several territories of Asian Russia, including Putorana and Anabar Plateaus, Yakutia, Transbaikalia and Amur River basin, has resulted in additional Schistidium collections. Some specimens of unclear affinity were studied for ITS1-2 sequences, and their comparison with previous data revealed two new and closely related species. They are described below under the names $S$. austrosibiricum and S. scabripilum.

\section{MATERIAL AND METHODS}

The work was based mainly on specimens recently collected by V.E. Fedosov in southern Taimyr and Putorana Plateau, by O.M. Afonina and I.V. Czernyadjeva in Zabaikalsky Territory, by S.V. Dudov in Amurskaya Province and by M.S. Ignatov and E.A. Ignatova in Yakutia. Some other collections from LE, MHA, MW and SASY were also studied.

New nuclear DNA ITS1-5.8SrRNA-ITS2 sequences were obtained from ten specimens, and 62 sequences from our previous studies were included in the analysis. Specimen data and Genbank accession numbers are in Appendix 1 .

DNA extractions and laboratory protocols were essentially the same as in Gardiner et al. (2005). Ampli- 
fied DNA fragments were sequenced in the Center of collective use "Genom" in Moscow. Sequences were aligned manually in Bioedit (Hall, 1999). Trees were rooted on Schistidium sordidum.

Bayesian analyses were conducted under a Bayesian Markov Chain Monte Carlo approach using MrBayes v.3.1.2 (Ronquist \& Huelsenbeck, 2003) with three compartments (ITS1, 5.8S and ITS2) analysed with HKY+I model for $5.8 \mathrm{~S}$, and with GRT $+\mathrm{I}+\mathrm{G}$ model for ITS1 and ITS2. Models were selected using ModelgeneratorV.85 (Keane et al., 2006). Three parallel runs were implemented, each with five chains and 20,000,000 generations ( $25 \%$ burnin).

Standard morphological and anatomical methods were used. Measurements were taken with Zeiss and Leitz light microscopes, cell sizes were measured on digital photos made with Nikon D70 camera and with the use of Infinity Analyze 5.0.2 Software. Drawings were made with MBS10 stereo microscope and LOMO Mikmed-2 light microscope with an aid of the Wild Heerbrugg TYP 308700 and RA6U42 drawing tubes.

\section{RESULTS}

The Bayesian analysis of the restricted set of accessions with an addition of new sequences resulted in the tree with topology similar to trees published by Ignatova et al. (2010, Figs. 1-2). It has a basal paraphyletic grade and maximally supported terminal clade with polytomy of four subclades, largely corresponding to Apocarpum-group, Atrofucum-group, Confertumgroup, and Frigidum-group, found in morphological studies of Blom (1996) and subsequenly supported by molecular phyloganatic analyses (Ignatova et al., 2010). The newly obtained accessions were found within a basal polytomy. Three specimens, previously identified as $S$. echinatum, from Putorana, Anabar Plateau in southern Taimyr and Indigirka River basin in Yakutia, form a clade with $\mathrm{PP}=1.0$ within a larger non-supported clade that includes also S. platyphyllum, S. grandirete and S. pulchrum. Note that morphologically very similar $S$. echinatum was resolved in Confertum-group within terminal clade, close to $S$. confertum, $S$. marginale and $S$. subflaccidum.

Another five new sequences from specimens originally referred to S. sinensiapocarpum, from Amurskaya Province, Zabaikalsky Territory, Buryatia and Altai, were also found in the basal grade. They formed a maximally supported clade, whereas 'true' S. sinensiapocarpum was found in basal paraphyletic grade, within a clade with $S$. sibiricum, with moderate support $(\mathrm{PP}=0.92)$.

These two groups of specimens were found to be distinct by this molecular phylogenetic analysis, and a study of their morphological characters also revealed some distinctions, which are discussed in the taxonomy section. They are described below as S. scabripilum sp. nov. and S. austrosibiricum sp. nov.

\section{TAXONOMIC TREATMENT}

Schistidium austrosibiricum Ignatova \& H.H. Blom, sp. nov. Figs.2-3.

The new species is similar to $S$. sinensiapocarpum in its papillose dorsal side of costa and long and coarsely spinulose hair-points in stem and perichaetial leaves, but differs from the latter in possessing shorter leaves (1.5-1.7 mm vs. $1.7-2.5 \mathrm{~mm}$ ), a more widened and flattened proximal portion of the hair-point, a mainly unistratose lamina, shorter and less sinuose median lamina cells and a different urn exothecial cell pattern with a considerable admixture of rectangular and isodiametric cells.

Holotype: Russia: Republic of Buryatia, Kurumkan District, Dzherginsky Nature Reserve, pass to Kovyli Creek, limestone outcrops, on rocks, 8.VII.2000, Tubanova 105(IV) (MW, Isotypes UUH, MHA).

Plants medium-sized to small, dull blackish- or brownish-green or dark-olivaceous above, brownish below, forming small to extensive tufts. Stem $0.5-1.5 \mathrm{~cm}$, repeatedly branched, in transverse section with 2-3-stratose sclerodermis, medullary cells with moderately thickened walls and narrow central strand. Leaves straight, appressed when dry, erecto-patent when wet, lamina $1.0-1.5 \times 0.5-0.6 \mathrm{~mm}$, from ovate base gradually narrowed into short triangular acumen, keeled distally, concave proximally; hyaline hair-points $0.3-0.6$ $\mathrm{mm}$, widened and flattened proximally, but rather stiff, straight, not decurrent, sharply serrate at margins and finely scabrose on dorsal surface; costa percurrent or extending into the proximal portion of hair-point, narrow, strongly projecting on dorsal side, semicircular in transverse section, mainly 3-layered, papillose on dorsal side in distal portion; margin recurved in proximal 2/3$3 / 4$ on one side and more shortly recurved on the other side in the widest part of leaf, flat distally and often papillose-denticulate below hair-point, bistratose in one row of cells; lamina smooth, unistratose or, rarely, with few narrow bistratose strips or patches; distal lamina cells isodiametric to transversely ovate, $6-9(-11) \mu \mathrm{m}$ wide and 6-10(-12) $\mu \mathrm{m}$ long, with moderately thickened, esinuose walls; median lamina cells subquadrate and shortrectangular, 7-9.5 $\mu \mathrm{m}$ wide and 7-15 $\mu \mathrm{m}$ long, with moderately thickened and slightly sinuose walls; basal juxtacostal cells rectangular, 9-11 $\mu \mathrm{m}$ wide and $12-25 \mu \mathrm{m}$ long, with moderately thickened esinuose walls, basal marginal cells in 5-7 rows subquadrate to short-rectangular, with thickened and porose transverse walls. Perichaetial leaves with oblong base and short triangular apical part, $2.0-2.5 \times 1.0-1.1 \mathrm{~mm}$, margins recurved in distal $1 / 2-2 / 3$, hair-point $0.6-0.8 \mathrm{~mm}$, widened and flattened proximally, decurrent or not, costa extending into its lover $1 / 3-1 / 2$ portion, margins sharply serrate, dorsal surface with shortly projecting upper angles of some cells. Calyptra cucullate. 

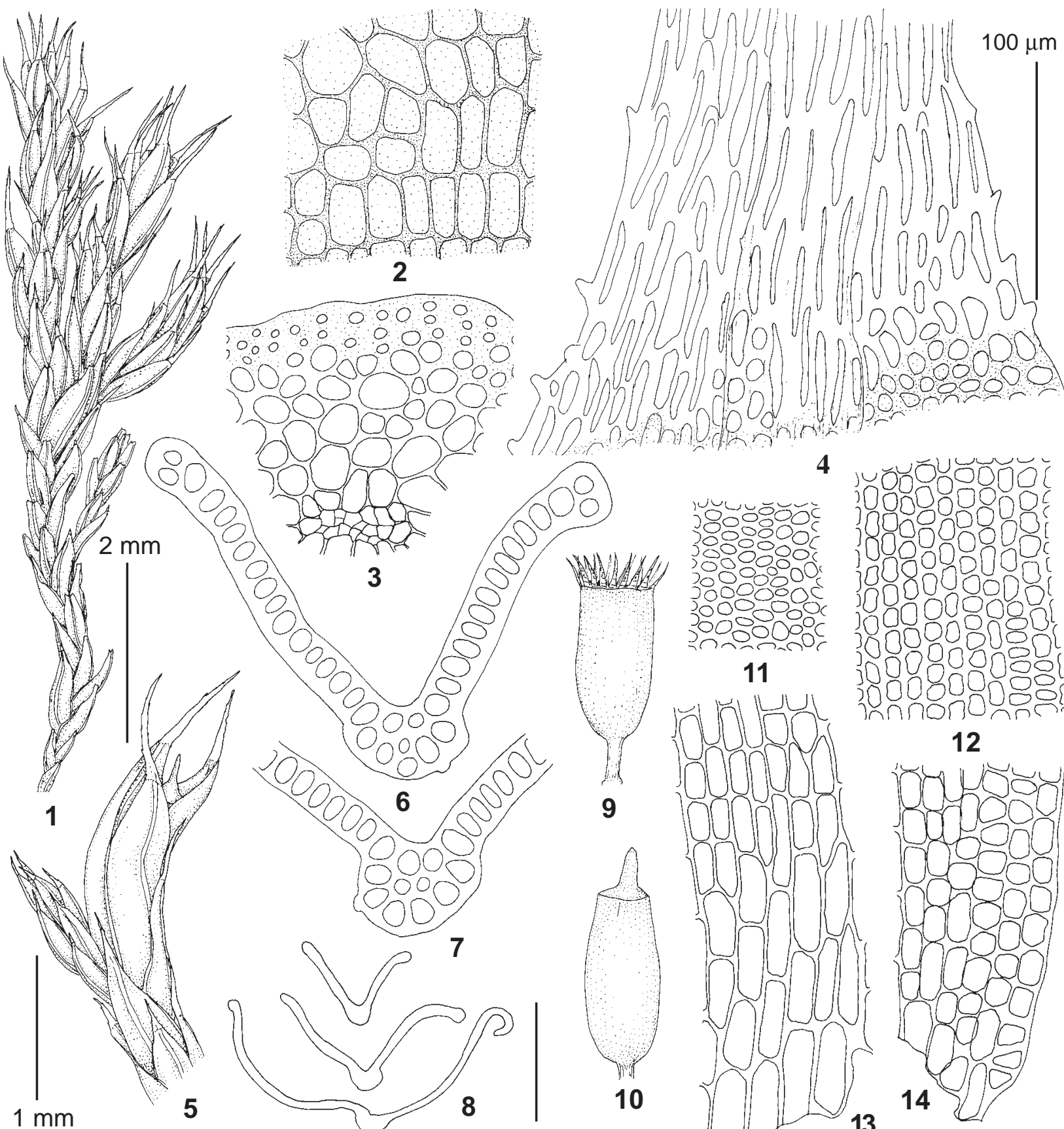

4

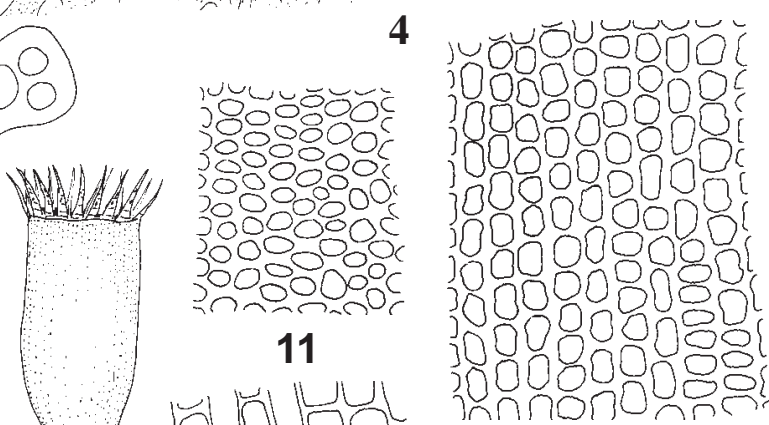

$1 \mathrm{~mm}$
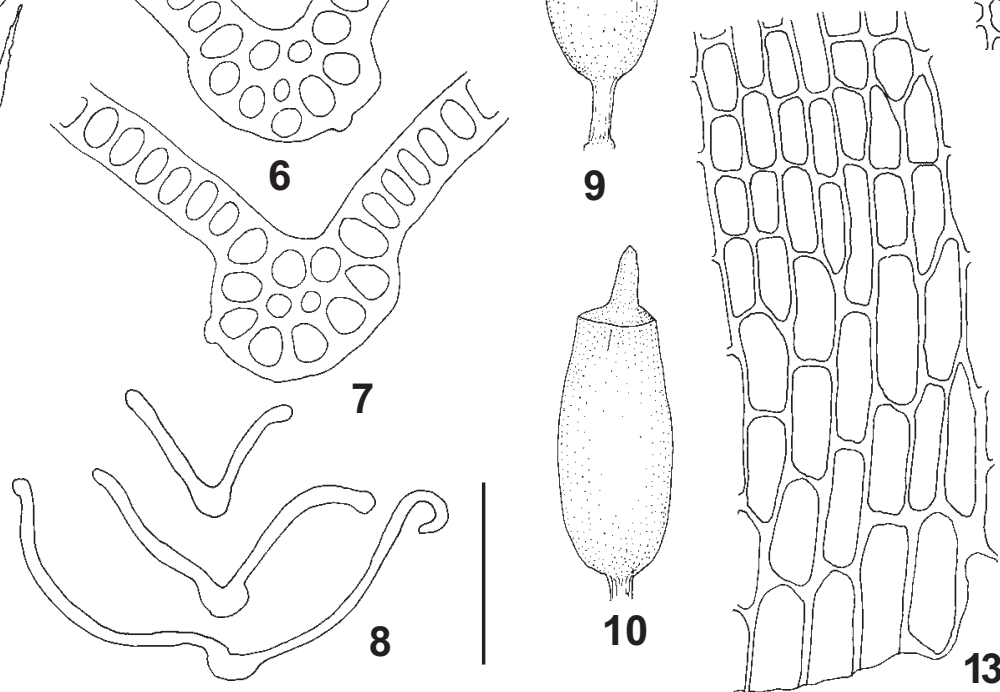

12

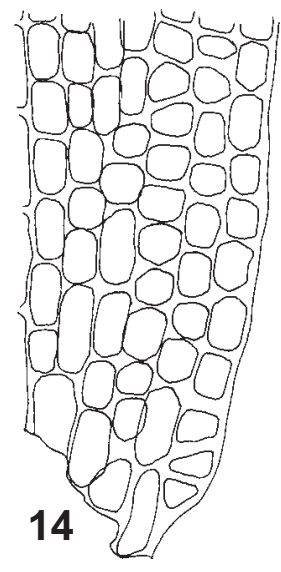

Fig. 2. Schistidium austrosibiricum Ignatova \& H.H. Blom (from holotype: Russia, Buryatia, 8.VII.2000, Tubanova 105(IV), MW). 1, 5 - habit, dry; 2 - exothecial cells; 3 - stem transverse section; 4 - distal lamina cells and lower part of hair-point; 6-8 - leaf transverse sections; 9-10 - capsules; 11 - distal lamina cells; 12 - median lamina cells; 13 - basal juxtacostal lamina cells; 14 - basal marginal lamina cells. Scale bars: $2 \mathrm{~mm}$ for $1 ; 1 \mathrm{~mm}$ for 5, 9-10;0.2 mm for 8; $100 \mu \mathrm{m}$ for 2-4, 6-7, 11-14.

Autoicous, sporophytes frequent. Seta $0.2-0.3 \mathrm{~mm}$. Urn immersed, elongate-cylindrical, $0.9-1.1 \times 0.5-0.6 \mathrm{~mm}$ (1.7-1.8:1), exothecial cells irregular, subquadrate and rectangular, stomata present at urn base; peristome teeth orange-brown, 320-340 $\mu \mathrm{m}$ long, with numerous perforations in distal half and some semiperforations in basal portion, densely papillose. Operculum conic, with long straight beak. Spores (10-)11-13 $\mu \mathrm{m}$, almost smooth.

Etymology. The species epithet refers to the main distribution area of this taxon in southern Siberia.
Distribution and ecology. The species occurs in southern part of Asian Russia, from Zeya River basin (Amur River tributary, Amurskaya Province) to the East and through Buryatia and Tyva to Altai Mountains to the West, with the northernmost localities in southern Yakutia. It was collected in mountain areas at low altitudes (ca. 300-950 m a.s.1.) within the forest belt, but mainly in dry and open places, such as limestone outcrops on mountain slopes, rocks in meadows and on steppe slopes. 


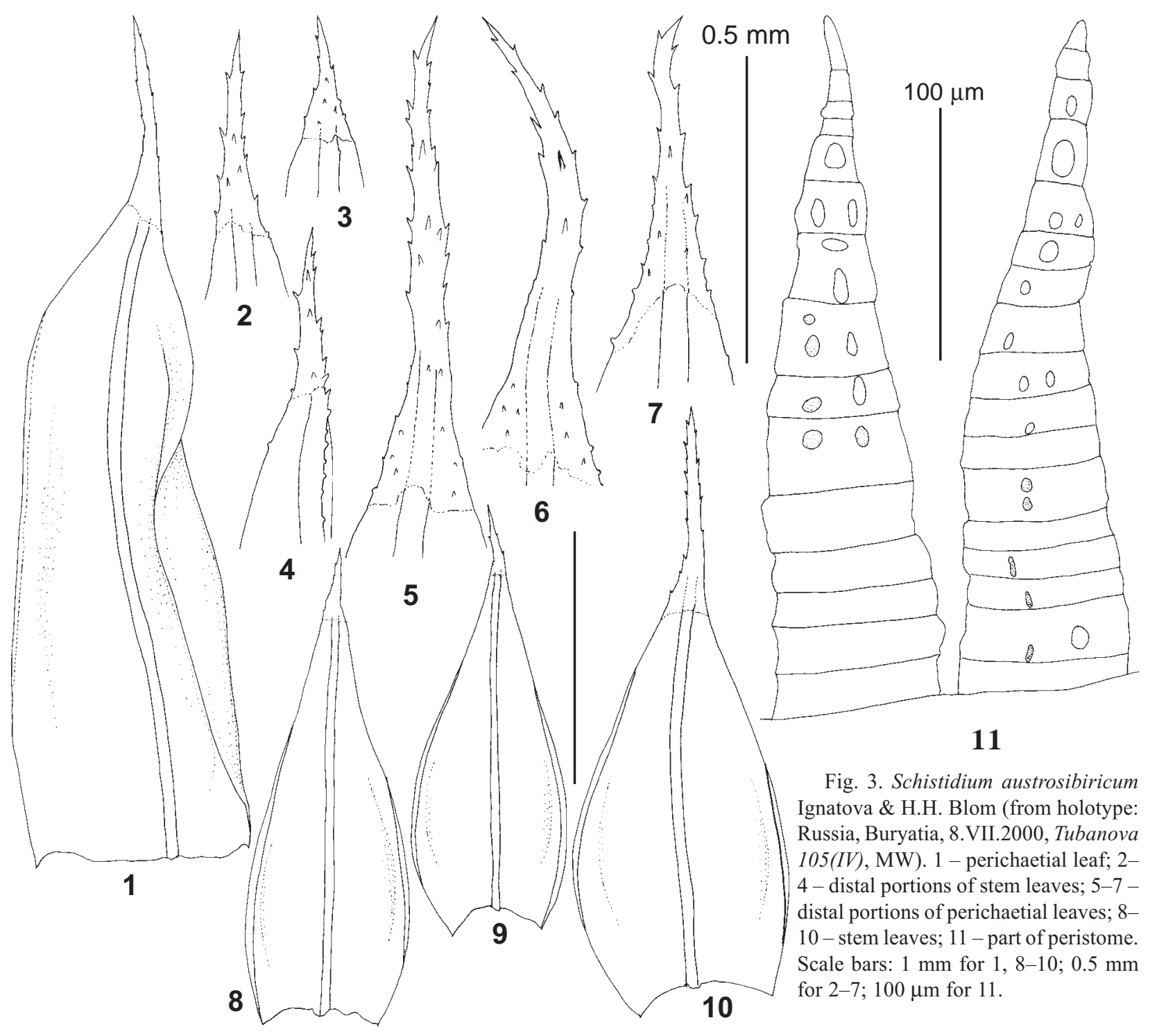

Relationship and differentiation. Schistidium austrosibiricum shares some essential morphological characters with $S$. sinensiapocarpum and Russian specimens of this novelty were previously named $S$. sinensiapocarpum. Both species have long and sharply serrate hairpoints in stem leaves and especially in perichaetial leaves. Their costae are usually papillose on the dorsal side, and leaf margins just below hair-point are often papillosedenticulate. Comparatively long cylindrical urns with length/width ratio 1.6-1.8:1 are also characteristic for both of them. However, S. austrosibiricum can be differentiated from S. sinensiapocarpum just under stereo microscope by its distinctly flattened, though rather stiff hair-points, whereas they are \pm terete throughout and only slightly widened at base in the latter species. Plants of $S$. austrosibiricum are slightly smaller with shorter stem leaves, (1.0-)1.5-1.7 mm vs. $1.7-2.5 \mathrm{~mm}$ and smaller length/width ratio (1.8-2.4 vs. 2.7-3.0). Microscopically, $S$. austrosibiricum has unistratose leaf lamina, with only one marginal row of cells bistratose, and only rarely with small bistratose strips or patches in distal leaf portion, whereas $S$. sinensiapocarpum possesses a partially bistratose lamina and more thickened leaf margins, 2-3stratose in distal part. Exothecial cells of S. austrosibiricum are variable in shape, with many elongate cells, while they are predominantly subquadrate and transversely rectangular in S. sinensiapocarpum.

S. austrosibiricum has some similarity with $S$. scabripilum, which is described below. The most striking morphological resemblance between them concerns their hair-point structure - distinctly flattened, but rather stiff due to the excurrent costa, and finely scabrose on dorsal surface because of shortly protruding upper cell angles. The differences of $S$. austrosibiricum towards $S$. scabripilum include unistratose vs. predominantly bistratose leaf lamina, almost esinuose vs. distinctly sinuose upper lamina cells, long vs. rather short urns and elongate vs. transversely rectangular exothecial cells. Furthermore, S. austrosibiricum usually grows on calcareous rocks, including limestone outcrops, while S. scabripilum prefers acid- 
ic and neutral rocks. Distribution areas of these species seem not to overlap: $S$. austrosibiricum is restricted to the southern mountain areas of Asian Russia, with northernmost locality in southern Yakutia (here on dry calcareous steppe slope), while $S$. scabripilum occurs much further north, in southern Taimyr and Putorana Plateau, in Indigirka River valley of Yakutia, and in Chukotka.

Two other species with flat hair-points and unistratose lamina described from Asian Russia, $S$. tenuinerve and $S$. bakalinii, differ from S. austrosibiricum in the smooth dorsal surface of hair-points. In $S$. tenuinerve, hair-points also tend to be shorter, to $0.4 \mathrm{~mm}$ vs. to 0.6 $\mathrm{mm}$ in stem leaves and up to $0.5 \mathrm{~mm}$ vs. $0.8 \mathrm{~mm}$ in perichaetial leaves, and they are softer, and distinctly more finely denticulate than in S. austrosibiricum. S. bakalinii has even longer hair-points (to $1.2 \mathrm{~mm}$ in perichaetial leaves) which are straight and rather stiff due to the longly excurrent costa. The leaves are shorter, 1.0-1.3 $\mathrm{mm}$ long, and differ from those of $S$. austrosibiricum in being narrow lanceolate with margins recurved almost throughout and possessing strongly sinuose median lamina cells.

All records of S. echinatum from Asian Russia were found to be erroneous, belonging mainly to $S$. scabripilum. The former species also has flattened and strongly spinulose hair-points, but the spinulae are longer, with rounded ends, and are often recurved at a right angle. The plants of S. echinatum are slightly smaller than those of $S$. austrosibiricum, and the hair-points of stem leaves are very short, while they are long and conspicuous in the latter species.

Specimens examined: RUSSIA: Republic Sakha/Yakutia: Aldansky District, Gynym River at $1 \mathrm{~km}$ upstream of Dyulyung Creek mouth, ca. $57^{\circ} 35^{\prime} \mathrm{N}, 130^{\circ} 11^{\prime} \mathrm{E}, 350 \mathrm{~m}$ a.s.1., 24.VII.1991, E.I.Ivanova s.n. (SASY, MW); Neryungri District, Chulman Settlement surroundings, ca. $56^{\circ} 51^{\prime}$ N. $124^{\circ} 53^{\prime} \mathrm{E}$, $600 \mathrm{~m}$ a.s.1., 25.VI.1993, E.I. Ivanova s.n. (SASY, MW). Amurskaya Province, Zeya District, Zeya Nature Reserve, Tukuringra Mountain Range, Izvestkovy ('Limestone') Bay of the reservoir and Izvestkovy Creek valley, 21.VII.2012, Dudov Br_12_038 and Br_12_120 (MW). Republic of Buryatia, Kurumkan District, Dzherginsky Nature Reserve, 9.VII.1999, Tubanova 161(IV), 121(4) (UUH, MW). Zabaikalsky Territory: Gazimuro-Zavodskiy District, Pryamoy Mulday River, $52^{\circ} 14^{\prime} 48^{\prime \prime} \mathrm{N}, 119^{\circ} 23^{\prime} 22^{\prime \prime} \mathrm{E}, 664 \mathrm{~m}$ alt., 22.VII.2012, Afonina 2812 (LE, dupl. MW); Nerchinsko-Zavodskiy District, near Nerchinsky Zavod Stettlement, Krestovka Mt., 51¹9'03.7'N, 119³5'53.1”'E, $658 \mathrm{~m}$ alt., 25.VII.2012, Afonina 3812 (LE, dupl. MW). Tyva Republic, Todzha Depression, Azas Lake, Ilgichul Brook, 1.VIII.1995, Otnyukova s.n. (MW). Altai Republic: Ulagan District, Chulyshman River valley 8-10 rm upstream from Chulcha River mouth, Ignatov \& Ignatova 12-420 (MW); Gorno-Altaisk Town surroundings, Saidys Creek valley, 6.VIII.2000, Ignatova s.n. (MW).

Schistidium scabripilum Ignatova \& H.H. Blom, sp. nov. Figs. 4-5.

Similar to S. echinatum in having a partially bistratose leaf lamina and flattened hair-points, but differs in longer hair-points covered by dense, but short, not recurved spinulae, longer stem leaves, longer median lamina cells with distinctly sinuose walls and predominantly transversely rectangular exothecial cells of the urns.

Holotype: Russia, Republic Sakha/Yakutia, Oimyakon District, Tuora-Tas River valley, 6439"32”N, $142^{\circ} 32^{\prime} 27^{\prime \prime}$ 'E. $900 \mathrm{~m}$ a.s.l., west-faced rubbly slope, on rubble and rock outcrops, 1.VIII.2015, Ignatov \& Ignatova 15-1048 (MW, Isotype MHA).

Plants medium-sized, dull, olivaceous or brownishgreen above, brownish below, forming small to extensive tufts. Stem 1-2 cm, repeatedly branched, in transverse section with 2-3-stratose sclerodermis, medullary cells with comparatively thick walls and moderately wide central strand. Leaves straight, appressed when dry, erecto-patent when wet, lamina $1.2-1.5 \times 0.5-0.6 \mathrm{~mm}$, from ovate base gradually or rather abruptly narrowed into triangular acumen, keeled distally, concave proximally; hyaline hair-points $0.25-0.6 \mathrm{~mm}$, widened and flattened proximally, but rather stiff, straight, shortly decurrent, moderately serrate at margins and finely scabrose on dorsal surface; costa percurrent or extending into the proximal portion of hair-point, narrow, strongly projecting on dorsal side, semicircular in transverse section, 3-4layered, smooth; margin recurved almost throughout, 2-3 $(-4)$-stratose in 2-3 rows of cells in distal 2/3,1-2-stratose at leaf base; lamina smooth, partially to almost completely bistratose in median and distal parts; distal lamina cells isodiametric, transversely ovate and shortly ovate, (6-)7-10.5 $\mu \mathrm{m}$ wide and (4-)6-9(-12) $\mu \mathrm{m}$ long, with moderately thickened, esinuose walls; median lamina cells subquadrate and short-rectangular, $7-9 \mu \mathrm{m}$ wide and 7.5-13 $\mu \mathrm{m}$ long, with moderately thickened and moderately sinuose walls; basal juxtacostal cells rectangular, 7-9.5 $\mu \mathrm{m}$ wide and $12-25(-40) \mu \mathrm{m}$ long, with moderately thickened esinuose walls, basal marginal cells in 5-7 rows subquadrate to short-rectangular. Perichaetial leaves with oblong base and triangular apical part, $1.9-2.1 \times 0.9-1.1 \mathrm{~mm}$, margins recurved in distal $1 / 2-2 / 3$, hair-points $0.6-0.9 \mathrm{~mm}$, widened and flattened proximally, shortly to longly decurrent, costa extending into its lower $1 / 3$ of hair-point or shorter, margins moderately to sharply serrate, dorsal surface finely and densely scabrose due to shortly projecting upper cell angles. Calyptra cucullate.

Autoicous, sporophytes frequent. Seta $0.2-0.3 \mathrm{~mm}$. Urn immersed, short-cylindrical, $0.7-0.8 \times 0.5-0.6 \mathrm{~mm}$ (1.3-1.4:1), exothecial cells subquadrate and transversely rectangular, stomata present at urn base; peristome teeth orange-brown, 225-250 $\mu \mathrm{m}$ long, with few longitudinal slits in distal portion or rather strongly perforated distally, densely papillose. Operculum conic, with long straight or oblique beak. Spores 9-12.5 $\mu \mathrm{m}$, almost smooth.

Etymology. The species epithet refers to the finely scabrose hyaline hair-points of stem and perichaetial leaves. 


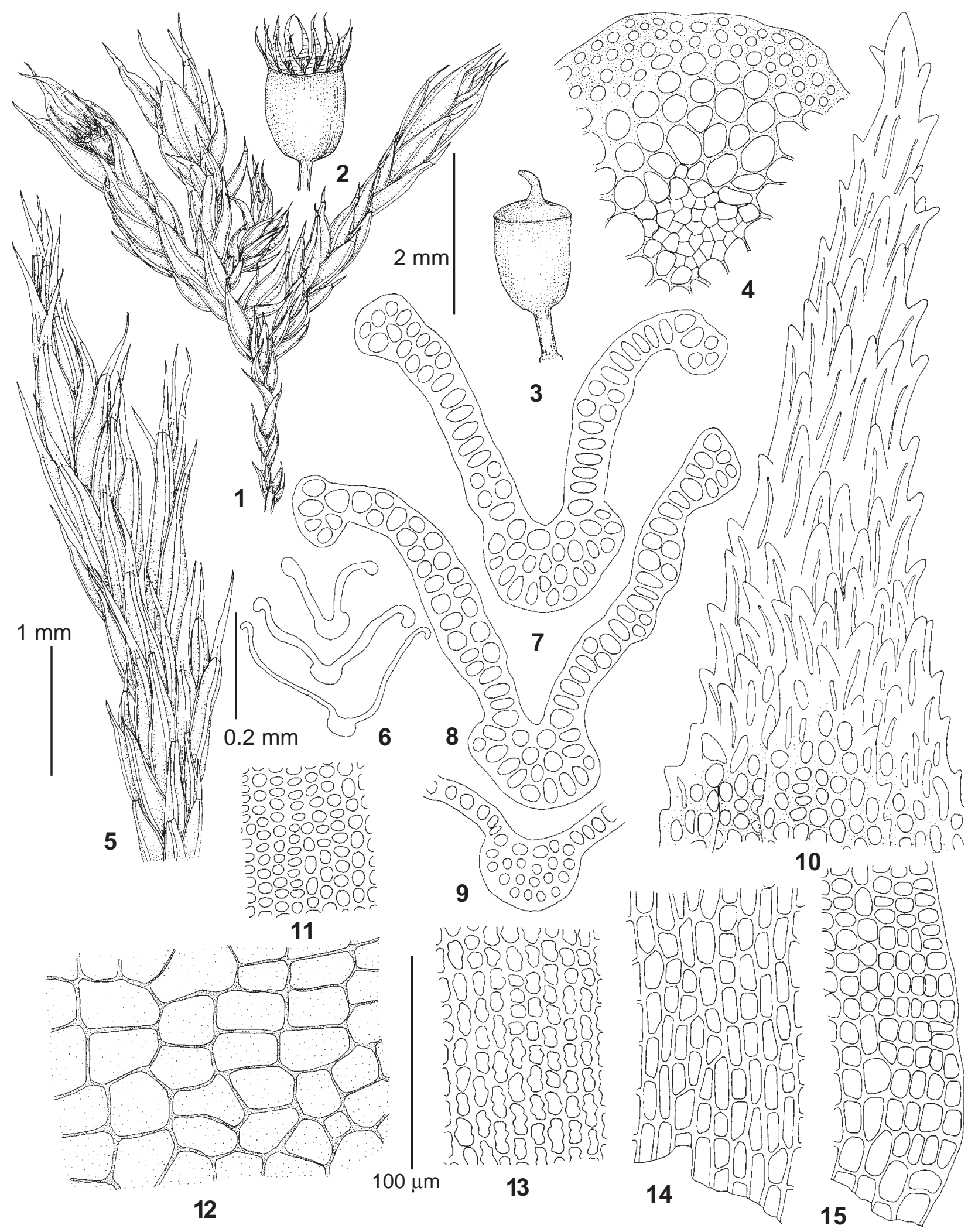

Fig. 4. Schistidium scabripilum Ignatova \& H.H. Blom (from holotype: Russia, Republic Sakha/Yakutia, Tuora-Tas River valley, Ignatov \& Ignatova 15-1048, MW). 1, 5 - habit, dry; 2-3 - capsules; 4 - stem transverse section; 6-9 - leaf transverse sections; 10 - distal lamina cells and hair-point; 11 - distal lamina cells; 12 - exothecial cells; 13 - median lamina cells; 14 - basal juxtacostal lamina cells; 15 - basal marginal lamina cells. Scale bars: $2 \mathrm{~mm}$ for $1 ; 1 \mathrm{~mm}$ for 2-3, 5; $0.2 \mathrm{~mm}$ for $6 ; 100 \mu \mathrm{m}$ for 4 , $7-15$. 


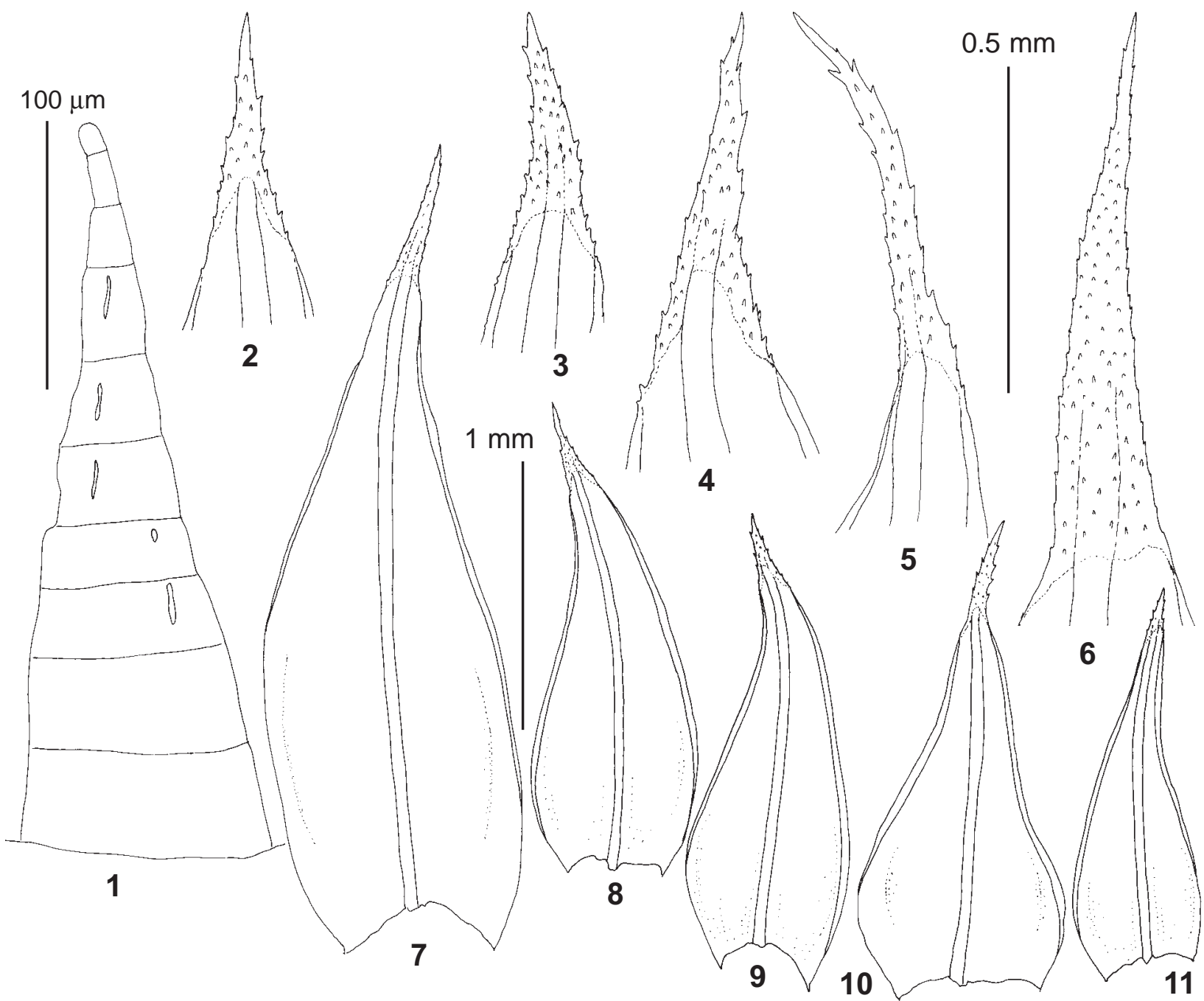

Fig. 5. Schistidium scabripilum Ignatova \& H.H. Blom (from holotype: Russia, Republic Sakha/Yakutia, Tuora-Tas River valley, Ignatov \& Ignatova 15-1048, MW). 1 - part of peristome; 2-4 - distal portions of stem leaves; 5-6 - distal portions of perichaetial leaves; 7 - perichaetial leaf; $8-11$ - stem leaves. Scale bars: $1 \mathrm{~mm}$ for 7-11;0.5 mm for 2-6; $100 \mu \mathrm{m}$ for 1 .

Distribution and ecology. S. scabripilum has a scattered distribution in mountain areas in the permafrost zone of Asian Russia. In addition to its type locality in Yakutia, it has been collected in Anadyr River basin in Chukotka, in southern Taimyr and on the Putorana Plateau. The species occurs at comparatively low altitudes, 250-900 $\mathrm{m}$ a.s.1. within the belt of open larch forests, and grows on siliceous rocks (sandstone, gneiss, dolerite, andesite, shist).

Relationship and differentiation. Habitually, $S$. scabripilum resembles S.pulchrum, which is very common and rather variable in north-east Asian Russia. However, its clearly flattened and densely scabrose hair-points and partially bistratose leaf lamina discriminate it from that species. It has often been identified as $S$. echinatum due to the superficially similar hair-point structure combined with a partially bistratose leaf lamina, which is also characteristic of $S$. echinatum. There are, however small, but constant morphological differences between these species. The hair-points in stem leaves of $S$. scabripilum are comparatively long, $0.25-0.6 \mathrm{~mm}$, whereas they never exceed $0.3 \mathrm{~mm}$ in $S$. echinatum and often consist of a few hyaline cells only; the dorsal side of hair-points is densely, but finely scabrose in S. scabripilum due to shortly protruding upper cell angles (though hair-points are rather sharply serrate at margins), whereas the dorsal spinulae consist of long, obtuse, finger-like protruding cell ends in S. echinatum. Exothecial cells of $S$. scabripilum are isodiametric and transversely rectangular, while they are mostly oblong and irregular in S. echinatum. These species have different distribution and ecological preferences: $S$. scabripilum is restricted to the permafrost zone of Asian Russia and grows on siliceous rocks, whereas S. echinatum is known from South Urals, the Caucasus, Austrian Alps and California in western North America and prefers calcareous rocks.

The distinction between $S$. scabripilum and $S$. austrosibiricum is discussed under the latter species. As in $S$. austrosibiricum, S. scabripilum can be separated from other Siberian species with flattened hair-points, i.e., S. bakalinii and $S$. tenuinerve, by the densely scabrose dorsal surface of hair-points, which is generally smooth in 
both the other species. Shorter leaves and flattened hairpoints are the main characters separating $S$. scabripilum from $S$. sinensiapocarpum, which also has a different distribution pattern.

Specimens examined: RUSSIA: Krasnoyarsk Territory: Taimyrsky Municipal District: Khatanga Settlement outskirts, Merkyu River valley 4 km upstream its mouth, Fedosov 11-289 (MW); Putorana Plateau, vicinity of Glubokoe Lake, Fedosov 150348 (MW). Chukotka: Anagyr District, upper course of Tanyurer River, Televeem Creek, 23.VII.1979, Afonina s.n. (LE, MW).

\section{ACKNOWLEDGEMENTS}

We are grateful to all who collected material for this study in remote and difficult accessable areas of Asian Russia. We also thank the curators of herbaria MHA, LE, SASY and UUH who made their collections available to us. The study of Ignatova was partially supported by RFBR grant \#15-04-06027 and of Kuznetzova by \#15-29-02647.

\section{LITERATURE CITED}

BLOM, H.H. 1996. A revision of the Schistidium apocarpum complex in Norway and Sweden. - Bryophytorum Bibliotheca 49: 1-333.

BLOM, H.H., H. BEDNAREK-OCHYRA \& R. OCHYRA. 2016. Studies on Schistidium (Grimmiaceae, Bryophyta) in Europe, with particular reference to the Alps: I. A description of $S$. marginale sp. nov. Phytotaxa 247(3): 210-218.

ELLIS, L. T., A.K. ASTHANA, P. SRIVASTAVA, I. OMAR, K.K. RAWAT, V. SAHU, M.J. CANO, D.P. COSTA, E.M. DIAS, N. DIAS DOS SANTOS, J.B. SILVA, V.E. FEDOSOV, M.N. KOZHIN, E.A. IGNATOVA, S.R. GERMANO, E.O. GOLOVINA, N.J.M. GREMMEN, R. ION, S. ŞTEFANUT,, M. VON KONRAT, M.S. JIMENEZ, G.M. SUÁREZ, T. KIEBACHER, M. LEBOUVIER, D.G. LONG, D. MAITY, R. OCHYRA, I. PARNIKOZA, V. PLÁŠEK, L. FIALOVÁ, Z. SKOUPÁ, S. POPONESSI, M. ALEFFI, M.S. SABOVLJEVIĆ, A.D.
SABOVLJEVIĆ, P. SAHA, M.N. AZIZ, J. SAWICKI, M. SULEIMAN, B.-Y. SUN, J. VÁŇA, T. WÓJCIK, Y.-J. YOON, J. ŻARNOWIEC \& J. LARRAÍN. 2016. New national and regional bryophyte records, 46. - Journal of Bryology 38: 47-63.

GARDINER, A., M. IGNATOV, S. HUTTUNEN \& A. TROITSKY. 2005. On resurrection of the families Pseudoleskeaceae Schimp. and Pylaisiaceae Schimp. (Musci, Hypnales). - Taxon 54: 651-663.

HALL, T.A. 1999. BioEdit: a user-friendly biological sequence alignment editor and analysis program for Windows 95/98/NT. - Nucleic Acids Symposium Series 41: 95-98.

GORYUNOV, D.V., E.A. IGNATOVA, M.S. IGNATOV, I.A. MILYUTINA \& A.V. TROITSKY. 2007. Support from DNA data for a narrow species concept in Schistidium (Grimmiaceae, Musci). - Journal of Bryology 29: 98-103.

HOFBAUER, W.K., L.L. FORREST, P.M. HOLLINGWORTH \& M.L. HART. 2016. - Preliminary insights from DNA barcoding into the diversity of mosses colonizing building surfaces. - Bryophyte Diversity and Evolution 38: 1-22.

IGNATOVA, E.A., H.H. BLOM, D.V.GORYUNOV \& I.A. MILYUTINA. 2010. On the genus Schistidum (Grimmiaceae, Musci) in Russia. - Arctoa 19: 195-233.

KEANE, T., C. CREEVEY, M. PENTONY, T. NAUGHTON \& J. MCLNERNEY. 2006. Assessment of methods for amino acid matrix selection and their use on empirical data shows that ad hoc assumptions for choice of matrix are not justified. BMC Evol. Biol., 6: 29.

MILYUTINA, I.A., D.V. GORYUNOV, M.S. IGNATOV, E.A. IGNATOVA \& A.V. TROITSKY. 2010. The phylogeny of Schistidium (Bryophyta, Grimmiaceae) based on the primary and secondary structure of nuclear rDNA internal transcribed spacers. - Molecular Biology 44(6): 994-1009.

OCHYRA, R. \& O.M. AFONINA. 2010. Schistidium frahmianum (Bryopsida, Grimmiaceae), a new arctic species from Beringia. - Tropical Bryology 31: 139-143.

RONQUIST, F., \& J.P. HUELSENBECK. 2003. MRBAYES 3: Bayesian phylogenetic inference under mixed models. - Bioinformatics 19: 1572-1574.

Appendix 1. Species of Schistidium used for molecular phylogenetic analysis of nrITS. For new sequences specimen data are given. Some specimens used in previous studies have two accessions numbers, for ITS1 and ITS2 separately.

$\begin{array}{llll}\text { S. } \text { austrosibiricum } & \text { Russia, Altai, Chulyshman } & \text { Ignatov \& Ignatova 12-420 (MW) } & \text { KX443486 } \\ \text { S. austrosibiricum } & \text { Russia, Amurskaya Territory, Zeya } & \text { Dudov BR_12_12_038 (MW) } & \text { KX443487 } \\ \text { S. austrosibiricum } & \text { Russia, Buryatia } & \text { Tubanova 105(IV) (MW) } & \text { KX443488 } \\ \text { S. austrosibiricum 1 } & \text { Russia, Transbaikalia } & \text { 25 July 2012, Afonina 3812 (MW) } & \text { KX443489 } \\ \text { S. austrosibiricum 2 } & \text { Russia, Transbaikalia } & \text { 22 July 2012, Afonina 2812/2 (MW) } & \text { KX443491 } \\ \text { S. pulchrum } & \text { Russia, Transbaikalia } & \text { 6 Aug 2012, Afonina 7312 (MW) } & \text { KX443492 } \\ \text { S. pulchrum } & \text { Russia, Transbaikalia } & \text { 25 July 2012, Afonina 3812/2 MW } & \text { KX443495 } \\ \text { S. scabripilum } & \text { Russia, Yakutia, Tupra-Tas } & \text { Ignatov \& Ignatova 15-1048 (MHA) } & \text { KX443493 } \\ \text { S. scabripilum } & \text { Russia, Krasnoyarsk, Putorana } & \text { Fedosov 15-0348 MW } & \text { KX443494 } \\ \text { S. sinensiapocarpum } & \text { China Sichuan } & \text { Koponen 46033 (H) } & \text { KX443490 }\end{array}$

S. agassizii Taimyr HM053879; S. apocarpum United Kingdom HM031076; S. atrofuscum Caucasus HM053887; S. boreale Altai DQ822025, HM031060; S. boreale Anabar 1 HM053888; S. boreale Anabar 2 HM053889; S. boreale Sweden HM053890; S. canadense Maine 1 HM053915; S. canadense Maine 2 HM053914; S. canadense Maine 3 HM053917; S. confertum Austria HM053891; S. confertum Austria JF262179; S. crassipilum Poland DQ822020, HM031073; S. dupretii Perm HM053895; S. echinatum Austria HQ890509; S. echinatum Caucasus HQ890508; S. elegantulum Caucasus DQ822022, HM031071; S. flaccidum Austria HQ890510; S. flaccidum Caucasus HM053899; S. frigidum Anabar HM053904; S. frigidum Taimyr HM053907; S. frisvolianum Anabar HM053908; S. grandirete Severnaya Zemlya HM053911; S. lancifolium Sakhalin HQ890512; S. liliputanum Byreya HM053918; S. marginale Austria HM053919; S. marginale Caucasus HM053921; S. maritimum Kuril Isl. HM053924; S. maritimum subsp. piliferum Norway HM053923; S. obscurum Anabar HM053900; S. obscurum Austria HQ890519; S. platyphyllum Anabar HM053926; S. pulchrum Anabar 1 DQ822031, HM031050; S. pulchrum Anabar 2 HQ890521; S. pulchrum Buryatia 1 DQ822028, HM031051; S. pulchrum Buryatia 2 DQ822032, HM031052; S. pulchrum Perm DQ822030, HM031053; S. sibiricum Buryatia HM053883; S. sibiricum Murmansk HM053885; S. sibiricum Trabsbaikalia HM053884; S. sinensiapocarpum Austria HM053939; S. sinensiapocarpum Caucasus HM053940; S. sordidum Anabar HM053942; S. sordidum Yakutia HM053943; S. subflaccidum Austria HM053945; S. subflaccidum Caucasus HM053946; S. submuticum Perm DQ822010, HM031056; S. submuticum St.-Petersburg DQ822009, HM031058; S. succulentum Caucasus HQ890523, HM053897; S. tenuinerve Altai HQ890525; S. trichodon var. nutans Austria HM053953; S. viride Missouri HM053957. 